\title{
Object Lessons: W. E. B. Du Bois and the Sturm und Drang of Race Childhood
}

\author{
Freeden Blume Oeur \\ Tufts University
}

Forthcoming: Journal of the History of Childhood and Youth, volume 14, issue 3 (2021). Special issue: "The Children of the Sun: Celebrating the One Hundred-Year Anniversary of The Brownies' Book"

Abstract: While originally referring to the use of material objects to convey abstract ideas, "object lesson" took on a second meaning at the turn of the twentieth century. This particular connotation - denoting a person and leader as moral exemplar - reveals fault lines between the thinking of W. E. B. Du Bois and G. Stanley Hall on young people. Through his own adoption of the German ideals of sturm und drang and bildungsroman, as well as "aftershadowing"-a recalibration of ideas and reflections on his own family genealogy, childhood, and intellectual lineages - Du Bois made ideological claims that were a counter-narrative to Hall's recapitulation theory.

Words: 10,655

The soul of "Of Our Spiritual Strivings," the first essay in W. E. B. Du Bois's collection The Souls of Black Folk (1903), is a meditation on Black childhood: future-oriented in the way it expresses yearnings, present-facing in the manner the essay lays bare the vulnerabilities but also the "dogged strength" of African Americans, and with an eye toward the past in its abiding concern for family genealogy and with its air of boyhood nostalgia. The essay was a revised version of an article that first appeared in 1897 in The Atlantic Monthly with the title "Strivings of the Negro People". ${ }^{1}$ It was a period of transition for Du Bois, who had arrived in Philadelphia the previous year with his wife, Nina, to begin research for what would become The

Philadelphia Negro (1899). He was also a new father, first to Burghardt, a son who was born in 1897 but died tragically soon after; his daughter, Yolande, was born in 1900 and later became a schoolteacher in Baltimore, where she taught for many years. ${ }^{2}$

My article tells a story about Du Bois and young Black people by considering Du Bois's reflections on his own childhood, family history, and life as a young adult, as well as how Du Bois's addresses to young people bespeak his own desires. My approach is subtextual and supratextual: subtextual in the way Du Bois's words in individual texts reflect his own desires and a struggle "for control over language, which for Du Bois is the greatest power"; 3 and supratextual in the manner that Du Bois's writings are related to one another across time, in a process I call aftershadowing. I draw on two ruminations on Du Bois in thinking about desire: first, from Claudia Tate, desire as the space negotiated between a Black author's "explicit, public, and racial identifications" and the "implicit, private psychological effects of narrative subjectivity"; and from R. A. Judy, desire as the connective tissue between charity and sacrifice, or "love at its most primitive level."4 Thus, following Tate, readers may trace desire upstream into the paratext, personal memories, and subconscious within Souls and other writings by Du Bois and encounter feelings of shame and pride; Judy instead foregrounds Du Bois's practice of 
renunciation, or selfless love in the service of others. These two formulations of desire make a dissonant pairing. But, to rephrase Du Bois's characterization of Black double consciousness, the purpose here is not necessarily to find a way to reconcile disparate strivings, but to find in them some manner of productive tension. ${ }^{5}$

My modest contribution in this essay is to suggest that tensions in Du Bois's writingsborn out of his ambivalent relationship with his childhood and family history, the embrace of a calling to a higher purpose, and a commitment to a democratic form of racial uplift — help to reorient thinking on child development and the education of young people at the turn of the twentieth century. Du Bois viewed himself as an object lesson for his race-a moral exemplar and living, breathing evidence of Black excellence - who was fated to navigate heroically the "storm and stress" of racial strife. ${ }^{6}$ I narrate this story by using Du Bois's well-known entanglements with Booker T. Washington to shine a light on Du Bois's less well-known relations with G. Stanley Hall. Du Bois and Hall exchanged cordial letters between 1904 and 1905 when Hall was president of Clark University. ${ }^{7}$ But my concern is with their respective and divergent uses of Sturm und Drang and the larger impulses of this German Romantic tradition, as well as how Du Bois's ideological claims offer a counter-narrative to Hall's recapitulation theory.

The chapters in Souls are not simply essays but sketches, as Du Bois calls them, and this view of the volume - as unpolished and extemporaneous - helps animate currents of dissonance and desire throughout the scholar's writings. The familiar portrayal of Du Bois is of a man with an authoritative, even formidable, voice; however, my essay situates Du Bois where he is caught between his reputation for being disciplined in habit and exacting in execution and the scholar's complex and elusive "psychological forces of subjectivity." I tread this area between as it is a preposition and analytic that held great meaning for Du Bois, who began "Strivings" and therefore Souls with the famous passage: "Between me and the other world there is ever an unasked question. . . . How does it feel to be a problem?"9 Nahum Dimitri Chandler finds in Du Bois's "syntactical" motivations behind the use of "between" a radical "opening of space" that "dissipates any simple notion of inside and outside, of above and below"; it is a movement that "joins and separates in the same status."

It helps to think of this movement of joining and separating like the path of a boomerang, as Black authors create, preserve, and repurpose their creations when they expect a delay before those creations become fully realized; a feeling of anticipation- "prolepsis" — that animates Black creative work. ${ }^{11}$ But this path is never totally circular; it is, rather, helical, as the boomerang motions over and over again to histories (one's own history and also intellectual lineages) and then propels forward to meet the specific demands of a current moment. I call this movement aftershadowing: for Du Bois, those moments of transition that involve reflection and the recalibration of ideas, a retrospective on earlier thoughts still under development, marked by “ends-as-beginnings." Here I am inspired by Chandler's idea of "epigraphic afterthoughts" in Du Bois's writing: the manner in which ideas are under constant revision and scrutiny and are hinged between texts. ${ }^{12}$ I am especially interested in how Du Bois's acts of aftershadowing undergird the changing relationship between individualism and collectivism, or those nested identities of a "Folk among Folks": ${ }^{13}$ for Du Bois (and as he urged of young Black people), a way of considering the dynamic (re)making of one's own identity (and intimate family ties) visà-vis the Negro people (a population with a shared soul and experience of double consciousness and, for Du Bois, a global people whose histories intersected with those of the world's darker races). More broadly, aftershadowing reflects one's own changing relationship in intellectual 
traditions and communities. Not a praxis in the service of teleology, aftershadowing finds harmony with what Katherine McKittrick calls method-making, a practice that is undisciplined in its transdisciplinarity: an "enactment of black life" that "may not necessarily take us where we want to go," but as McKittrick, citing Édouard Glissant, writes, to "an unknown that does not terrify." 14 This process brackets the kind of foreshadowing that does not necessarily hint at likely outcomes but expands the horizon of possibilities in future endeavors.

Given my article's focus on young people and schooling, I am also thinking of ends-asbeginnings as actual events: school commencements, those final rituals that mark entry into a new life. Aftershadowing is not merely a reconsideration of initial thoughts (of what is to come, or foreshadowing) but is itself forward-looking, in anticipation of transition and incompleteness. Before embarking on a career as a scholar and activist, Du Bois honed his oratory skills as a student and spoke at both his high school graduation in 1884 and his Harvard commencement in 1890. Throughout his career, Du Bois was a sought-after high school and college graduation speaker. Given the many invitations he accepted and speeches he delivered (and in some cases, preparing speeches that he never delivered), as well as the numerous teaching roles he held (teaching wildly different subjects to a range of age groups), his entire life was bracketed by an academic calendar. The term "commencement" might seem odd for a closing ceremony, but the term is meant to signify the start of one's life as a graduate. For Du Bois, they were opportunities for reflection and aftershadowing, incubators for ideas that could travel in unanticipated ways to accommodate unforeseen problems. Du Bois's own educational training inspired him to think capaciously about how the German bildungsroman - the coming-of-age story-in tandem with the dissonant chime of Sturm und Drang could be adapted to understand the "race-childhood" of Black Americans.

This helical movement travels through "archives" in the broadest sense of the term: not just a site of preservation, but a discursive field covering a range of texts. ${ }^{15}$ Archives are also memories - haunting, fleeting, imperfect — as Du Bois wrote at the end of his long life. ${ }^{16}$ Du Bois drew on a range of sources to help him translate his own and the collective memory of his people. While his New England upbringing and family history may have created some distance between him and other Black Americans, Du Bois saw in self-reflection and personal history an opportunity to articulate a collective biography; as he wrote in Dusk of Dawn (1940), "My life had its significance and its only deep significance because it was part of a Problem. . . I seem to see a way of elucidating the inner meaning and significance of that race problem by explaining it in terms of the one human life that I know best." ${ }^{17}$ Du Bois's affection for using the ideas of canonical figures (including, as I discuss herein, Goethe, Dante, and Wordsworth) to help translate the feelings of a diasporic people has made Du Bois vulnerable to accusations of elitism and of being too keen to embrace Eurocentric ideas. But this affection shows quite clearly how the scholar remained committed to the belief in the transformative potential of a classical, liberal education. The Souls of Black Folk nods to the likes of Aristotle, Shakespeare, and Balzac, but for $\mathrm{Du}$ Bois these figures are not to be venerated so much as their ideas are to be adapted in the service of racial struggle. Thus, I agree with David Krell that if, as Du Bois writes in Souls, education is a matter of making "fine adjustments" in order for knowledge to keep pace with the problems of real life, then "Du Bois is concerned to let as many hands as possible work the adjustment." 18 My hope is that revisiting a well-studied topic in Du Boisian scholarship- how European romanticism and training in Germany shaped Du Bois's thinking on matters of racewill help make more Du Boisian inroads into the study of American childhood. 
Water has long been a favored metaphor in Black Studies, ${ }^{19}$ and so when Jean-Christophe Cloutier writes that when Black archival work washes "up on the shores of the present, it inevitably brings something from the sands of the past," we might imagine Du Bois's boomerang tracing a path forward to his 1920 collection Darkwater: Voices from Within the Veil. This volume begins with a postscript. In it, Du Bois wonders what more he can say about the great human drama beyond "what great souls have already said." ${ }^{20}$ His humble ambition is to strike a "half-tone, up from the heart of my problem and the problems of my people." Here the "problem" is not the subject of a question, as it is at the start of Souls, but it remains unresolved. The seventeen years that passed between the publication of the two texts were an extraordinarily productive and demanding time for Du Bois, but he confesses his writings may still have only little to contribute - a half-tone, referencing the smallest possible interval in musical notation. But I want to stress a second possible interpretation of what motivates Du Bois here. Du Bois's half-tone, or semi-tone, resists the urge to move a full step (or interval); it invites readers to consider the "feel" of dissonance (the experience of double consciousness, or "How does it feel to be a problem?") that marks the area between the borders delimited by a full step. In marking "between" as dissonant and unstable, I continue Chandler's "paleonymic" project of revising and reworking old words. ${ }^{21}$ By reflecting back on the enduring "problem" that captivates Souls, the postscript to Darkwater is also a postscript on Souls, an act of returning to (being honest with, questioning, amplifying) one's own old words; a shadow, therefore, is not merely a conceptual device for Du Bois, but, again, a manner of method-making, a way of imagining and creating work over time, as the outer reaches of Souls's long shadow_its "penumbra of vagueness" 22 envelops Darkwater. A text that will cast and encircle future writings in its own shadow.

A postscript comprises those final thoughts when a work is complete and then added to the start of a text: another end-as-beginning. It is a mode of transition, sense of renewal, and position of betweenness - that which joins and separates what has ended and what has startedthat I stress in this essay. This framing also reveals The Brownies' Book as not an afterthought to publications like Souls, Darkwater, and Dusk of Dawn, but as a companion piece to these volumes. The Brownies' Book paired images of Black joy and ordinary play ${ }^{23}$ with assertions of Black children as living, breathing object lessons, a term that held great meaning in Du Bois's time and the topic to which I now turn.

\section{Object Lessons and the Vision Splendid}

My reflections on Du Bois's interstices are a way of understanding object lessons, which are featured in each issue of the Journal of the History of Children and Youth. During Du Bois's primary school days in Great Barrington, Massachusetts, object lessons-exercises where students used (touched, smelled, listened to) everyday objects to learn about abstract conceptswere a mainstay in schools across the United States. Today, "object lesson" is shorthand for a poignant example of something, typically a concrete event - one that is accessible or visceral in the way it engages our senses and emotions - that communicates an abstract idea. Sarah Anne Carter describes how object lessons have long conveyed messy truths about race and racism in the United States. ${ }^{24}$ To offer a recent example: a widely circulated New Yorker article by Keeanga-Yamahtta Taylor at the start of the COVID-19 pandemic asserted that "the pace at which African-Americans are dying has transformed this public-health crisis into an object lesson in racial and class inequality." 25 As Taylor conjectured, COVID's toll on Black Americans has forced a reckoning with the central place of anti-Blackness in the nation's history. This understanding of object lesson resonates with another phrase with origins in schooling and 
which has now been adopted widely: "teachable moment," or when an unplanned event provides an opportunity to learn something important. We are right to be suspicious of innocuoussounding terms like "teachable moment" and "object lesson" when trying to understand racism and racial violence, but they do help to focus our attention on the nexus of youth, schooling, and morality in Du Bois's thought.

These two meanings of object lesson - as the material that conveys the abstract, as teachable moment - surface in the second paragraph of "Of Our Spiritual Strivings." It contains this childhood memory:

I remember well when the shadow swept across me. I was a little thing, away up in the hills of New England, where the dark Housatonic winds between Hoosac and Taghanic to the sea. In a wee wooden schoolhouse, something put it into the boys' and girls' heads to buy gorgeous visiting-cards - ten cents a package — and exchange. The exchange was merry, till one girl, a tall newcomer, refused my card, - refused it peremptorily, with a glance. Then it dawned upon me with a certain suddenness that I was different from the others; or like, mayhap, in heart and life and longing, but shut out from their world by a vast veil. $^{26}$

Du Bois often reflected fondly, in romanticized terms, on his boyhood days in the Berkshires of western Massachusetts. As he wrote in Dusk of Dawn, the town of Great Barrington was “a boy's paradise: there were mountains to climb and rivers to wade and swim; lakes to freeze and hills for coasting." 27 But here Du Bois recalls the precise moment when he first understood that he was to live a life behind the racial veil, his chosen metaphor for the color line; a veil that falls heavy and separates Blacks and (white) Americans. At the age of ten, a white girl had spurned his exchange of a "visiting-card"; consequently, "the theorems of playground sociology were ... forever shattered." 28

Had Du Bois been born two decades later, this jarring experience may have featured not visiting cards but Brownies - those mass-produced tintype cameras that were popular among children and were one inspiration for the name of The Brownies' Book ${ }^{29}$ - and a memory of how the newcomer had refused to have a picture taken with young William. Still, it helps to imagine Du Bois as a photographer gifted with "second sight" (as he writes in "Strivings"); he freezes this moment and urges viewers to turn their gaze to a "glance" (eyes looking away: the chosen perspective of those outside the veil) and next to imagine the look on Du Bois's face when the veil descends. Still, there remains the material object at the heart of the memory: something so harmless, even precious: a visiting card. By purchasing and exchanging these cards among themselves, Du Bois and his classmates were imitating an adult bourgeois practice of the era. Originating in Europe, visiting cards, also known as "calling cards," were used within elite circles to signal one's status and desire to "call" on, or visit, someone else. A strict social etiquette guided their use. They were sometimes plain and simply featured one's name, with space for a handwritten note. Or they could be decorated with images, a seal, or an affiliation. It is charming to imagine these schoolchildren personalizing their visiting cards and writing notes for one another. That Du Bois may have had a special romantic affection for this "one girl" is also important, as men of the era had used visiting cards to court women. Being rejected by the newcomer "with a glance" spoke volumes and signals a larger history of troubling sexual politics between white women and Black men. ${ }^{30}$ This schoolhouse memory was an object lesson for Du Bois: the simple, concrete thing of a calling card - the size of a playing card, made of thin 
cardstock, fragile and easily lost — conveyed a deeper moral story that Du Bois would narrate for others for the remainder of his long life. David Levering Lewis contends that Du Bois was not normally concerned with getting the details right when relaying his personal memories; instead, with the aid of his literary talents, Du Bois invited readers to reflect on the materiality of an object like a visiting card before adjusting focus to the moral of the story.

Object lessons took on another distinct meaning in the second half of the nineteenth century. Physical objects - and therefore object lessons - were a centerpiece of the Hampton Normal and Agricultural Institute, founded after the Civil War in Virginia. The institution's "education for life" mission emphasized experiential learning and a curriculum that was "scientific rather than classic." 31 School founder Samuel Armstrong wanted "to build up an industrial system for the sake not only of self-support and intelligent labor, but also for the sake of character." 32 The success of Hampton reflects a turn-of-the-century accommodationist strategy promoted by Booker T. Washington. Born a slave but later becoming the most wellknown Black leader in the United States, Washington attended Hampton as a student before being recruited to lead the new Tuskegee Normal and Industrial Institute in Alabama. In Washington's eyes, Hampton graduates themselves were object lessons: the living embodiments of a larger strategy of Black racial uplift. They would be "a class of leaders who go out among the people as object lessons, as centers of light." 33 Washington's name became synonymous with the notion of "object lessons" at the turn of the twentieth century, and even reflections on Washington's mixed legacy continue to draw on the metaphor. ${ }^{34}$

Historical accounts have long rehearsed the disputes between Du Bois and Booker T. Washington, as the two leading "race men" of their era who adopted the contrasting ideological stances of Black resistance and Black accommodation, respectively. To be sure, Du Bois's thinking would evolve to embrace vocational training, but at the turn of the century he advocated resolutely for a classical education that would produce a different "class of leaders": Black professionals and intellectuals. Du Bois made this point clear enough when, to his surprise, he was invited to speak at Hampton in 1906. At that point, Du Bois observed, the United States was "obsessed with what may be called the Hampton-Tuskegee idea of Negro education." ${ }^{35}$ Critical of this obsession with vocationalism, Du Bois told an "outraged" audience that higher education ought to train "the most promising" for a life of thinking and leading. ${ }^{36}$

Du Bois stressed that graduates of Negro colleges could serve as object lessons for their race. In "Strivings," a second poignant memory emerges soon after the schoolhouse memory in the same paragraph. Du Bois borrows eagerly here from William Wordsworth's Romantic-era poem "Ode: Intimations of Immortality from Recollections of Early Childhood" (1807). ${ }^{37}$ A year after the original "Strivings" essay first appeared, Du Bois gave the commencement address at his alma mater, Fisk University. He began: "I heartily join in congratulating you to whom has been vouchsafed the vision splendid." "38 Speaking to the young people who sat where Du Bois himself had sat ten years prior, Du Bois urged the graduates to reflect on what a blessing it was that their liberal education - their "vision splendid" - could offer "a glimpse of the higher life, the broader possibilities of humanity." 39 This idea of the vision splendid, as Robert GoodingWilliams observes, was adapted from the fifth stanza of "Ode," when Wordsworth reflects on the energy and potential of youth. ${ }^{40}$ According to Gooding-Williams, Du Bois came to understand at the schoolhouse that his own vision splendid - his sublime origin — was corrupted, as " $t]$ he shades of the prison-house closed round about" him, language that appears in the original 1897 essay as well as the Souls version and which is adapted from Wordsworth's "Ode." As the veil's shadow descended, Du Bois responded (as he later wrote in Dusk of Dawn) by cultivating a 
resilient "inner life." And the end, as it were, was just a beginning (a "commencement") for the graduates; when Du Bois returns to Fisk as graduation speaker, he is imparting the necessity of inner fortitude for the Black youth and for the cultivation of exemplary Blackness.

Du Bois's choice of words for how the vision splendid was gifted to the young people in the audience - it was vouchsafed - will return in Souls's own "commencement": the book's afterthought, the conclusion-as-beginning. Here, he implores his readers that they "vouchsafe" that his "book fall not still-born into the world-wilderness." ${ }^{11}$ Du Bois's choice of words are an act of aftershadowing, as Du Bois reflects on the start of his own fated journey, a decade before, through the sturm of the "world-wilderness."

\section{Storm and Stress}

G. Stanley Hall observed with keen interest the sparring between Washington and Du Bois. The racial politics of Hall's early childhood psychology are now well known. Mickenzie Fasteland reminds us that G. Stanley Hall's two-volume tome, Adolescence: Its Psychology and its Relations to Physiology, Anthropology, Sociology, Sex, Crime, Religion, and Education (1904), was racist and paternalistic because it relied on a recapitulation theory drawn from neoLamarckian ideas of progress. ${ }^{42}$ The notion of Sturm und Drang ("Storm and Stress") was central to this formulation of adolescent development. As Hall wrote, during adolescence, individuals recapitulated the evolution of humans from savage to civilized. Other American psychologists of this period relied on notions of essential racial difference in viewing the development of the white child as an index for the development of the race. ${ }^{43}$ "The child comes from and harks back to a remoter past; the adolescent is neo-atavistic, and in him the later acquisitions of the race slowly become prepotent," Hall argued. "Development is less gradual and more saltatory, suggestive of some ancient period of storm and stress when old moorings were broken and a higher level attained." 44 "Storm and stress" appears again in the pivotal final chapter of Volume I. As Fasteland explains, this chapter revealed Hall's interest in "ephebic literature," a genre showing teens how to navigate adolescence by using case studies of leading men (and some women) from literature, mythology, biographies, and diaries ${ }^{45}$ Hall cites the work of his doctoral advisee, William Burnham, who first used Sturm und Drang to describe the chaos but also radical potential of adolescence and who was similarly captivated by ephebic literature as a fount of lessons on adolescent development.

Sandwiched between descriptions of Pierpont Morgan and Vittoria de Feltre was Booker T. Washington, who, according to Hall, "at about thirteen or fourteen ... felt the new meaning of life and started off on foot to Hampton, five hundred miles away, not knowing even the direction, sleeping under a sidewalk his first night in Richmond." 46 This brief passage speaks volumes. Hall describes Washington as having found his calling and having beat extraordinary odds to become a leader for his race. Hall pinpoints this discovery of a "new meaning" in Washington's adolescence and assigns Washington's life story to the hallowed shelves of ephebic literature. Washington's self-help racial politics and industrial education received a major boost from the preeminent childhood psychologist. In Adolescence, Hall speculated that this education - here acknowledging explicitly the accomplishments of Hampton and Tuskegee - was so promising that Blacks would soon enjoy greater economic and social standing than poor whites. In this way, Blacks would become a "wedge" group between poor whites and upper-class whites:

The future of the entire black race is today more hopeful than ever before, chiefly from 
the work of one negro, Booker Washington, who is perhaps solving not only our negro problem but that of the Dark Continent, as well as providing object-lessons for colonial statecraft the world over. As autocrat of the Philippines he would probably accomplish what armies and white pedagogues and Congress can never do. ${ }^{47}$

Hall's use of "object-lessons" has several meanings. There is an endorsement of Washington himself as the preeminent object lesson, or moral leader, for his race. Hall also offers Washington's industrial training as a model for imperial expansion around the globe, in that evolutionary logics held that colonized peoples could effectively assimilate by being taught to be self-sufficient as a group. Washington suggested as much in a newspaper article published the same year as Adolescence, in which the leader addressed a shortage of Black labor in the rural South. His language is telling, as Washington assured readers "that by mutual understanding and sympathetic co-operation each of these two races of the South can help forward the interests of the other, and thus cement a friendship between them that shall be an object lesson for all the world." 48

The partnership between Washington and Hall had important repercussions for Du Bois. As Fasteland notes, "Hall, likely already familiar with Du Bois' work, chose a specific image of the African-American ephebe, one that disavowed Du Bois for another who correlated with his own imperialist goals. As such, Washington's inclusion functioned as a corrective for any African-American or 'ethnic' adolescent interested in radical racial equality." ${ }^{49}$ Indeed, Hall never mentions Du Bois by name in Adolescence, even though in the paragraph immediately preceding his reference to Washington and object lessons, Hall writes approvingly of the Atlanta University publications (a series of research studies on Black Americans), efforts that were led by Du Bois.

Two years after the publication of Adolescence, Hall would praise Du Bois's The Souls of Black Folk in a lecture titled "The Negro in Africa and America," and even Du Bois's appeal for a college education for a select group of Blacks. But Hall's essay consolidates the worst of the period's scientific racism in claiming that the subordination of Africans was a result of their uncivilized natures and physical and psychic limitations. Hall remained satisfied with Washington's industrial philosophy, which groomed Black respectability and did little to disrupt the existing racial hierarchy:

At this point of Southern despair came one of those masterly pieces of statecraft in the last century - masterly because so simple - in the policy of Booker Washington. Let our race, he said, be as separate socially and politically from the whites as the ten fingers, though industrially as united with them as the fingers are united in the hand. Under the reconstruction era, he says that the chief desire of all bright young negroes was to hold office and to study Latin, and he declares that it is against these two desires that the efforts of his life are directed. ${ }^{50}$

Just as Hall proposed that the development of white children into adulthood recapitulates human evolution, Du Bois's mission was to critique the very foundations of this "racialized modernity"- the contemporary period's entanglements of racism and colonialism - that nurtured those racist recapitulation theories and, by extension, visions of desirable white childhoods and desirable white futures. ${ }^{51}$ 


\section{Of Our Spiritual Storms}

In the chapter of Adolescence in which Washington's name first appears - in a section covering "current biographies of well-known modern men"-Hall's first example of a famous figure is notable. As Hall surmised, Johann von Goethe's biography is incomparable for it reveals an adolescence marked by deep reflection and development of consciousness, by someone who "has exploited all available resources of the genetic period of storm and stress more fully perhaps than any other writer." 52 While Hall himself may have used a "corrupted" version of Sturm und Drang, the phrase and larger German Romantic movement synonymous with Goethe served as guiding lights for the young Du Bois. ${ }^{53}$ In the German bildung, Du Bois found a philosophy for linking self-consciousness and group membership through intensive self-improvement. ${ }^{54} \mathrm{Du}$ Bois's task would be to adopt a philosophy of self and collective growth stressing a "a telos conceived as the harmonious development of all their various capacities" 55 as an aim in the larger struggle to overcome the twentieth century's "problem of the color-line."

In the autobiography published after his death, Du Bois reflects on his transformative two-year period in Germany, beginning in 1892, not long after he had started his doctoral studies at Harvard. The then-nonagenarian recalls his twenty-fifth birthday in Germany, while a student at the University of Berlin, spent "lonesome and far away from home and boyhood friends." 56 This solitary event notwithstanding, his time in period in Germany was transformative and liberating, and he would even remark that he faced less racism than he had in the United States. ${ }^{57}$ On that occasion, Du Bois accepts his calling as a leader for his people and he drafts an itinerary for his life's work. With strong echoes of the opening lines of Dante's Divine Comedy, Du Bois steels himself for the road ahead: "I will in this second quarter of my life, enter the dark forest of the unknown world for which I have so many years served my apprenticeship - the chart and compass the world furnishes me I have little faith in - yet, I have none better-I will seek till I find-and die." ${ }^{58}$ Du Bois had prefaced this observation with: "I wonder if life is worth the Sturm - I do not know_- perhaps I never shall know; but this I do know: be the Truth what it may I will seek it, on the pure assumption that it is worth seeking and Heaven nor Hell, God nor Devil shall turn me from my purpose till I die." 59 In a volume of Du Bois's unpublished writings, Herbert Aptheker will translate "Sturm" in this passage as "striving," an act worth taking seriously given Aptheker's long and close friendship with Du Bois and Aptheker's role as Du Bois's literary executor. Aptheker's editorial decision is nontrivial. This translation reveals Sturm und Drang as not a mere metaphor but the essential spirit of the "Strivings" essay; indeed, we might even speculate on a translation of the title of the essay as "Of Our Spiritual Storms."

In many respects, Du Bois's final autobiography is a collection of afterthoughts for Souls. It is also a final statement on the impact that Goethe had on Du Bois. The book ends with Du Bois writing, "You are not and yet you are: your thoughts, your deeds, above all your dreams still live . . . there is no Dream but Deed, there is no Deed but Memory." If, for Du Bois, in the end (of his own life) was the deed-purposeful, conscious action that lives on and inspires future generations - then Du Bois is again aftershadowing. These lines riff on main character Faust's pronouncement - "In the beginning was the deed," in Goethe's classic (a revision of words which itself is an act of paleonomy), a tragedy concerning a philosopher who yearns for the sublime experience of unbounded knowledge. ${ }^{60}$ The essence of the deed is striving, or strebhen, a foundational idea in Goethe's Faust that could be said to be the major guidepost for Du Bois's intellectual itinerary in Germany. ${ }^{61}$ In the essay "Of the Wings of Atalanta" from Souls - and later in his autobiography_Du Bois borrows the proclamation "Entbehren sollst du, sollst entbehren" ("Renounce shalt thou, thou shalt renounce") from Faust to again emphasize the 
need for a higher training of Black Americans. The "unfettered striving" that accompanies the "vision of life" crystallizes for Du Bois in a "Gospel of Sacrifice" (or renunciation): acts of service in the struggle for racial advancement.

Du Bois viewed himself as a descendant of a lineage inaugurated by the Stürmer und Dränger, noble creatives who had sought "to develop the totality of their capacities." 62 A disciplined self-development was essential for collective uplift. Sturm und Drang appears in both the earlier 1897 "Strivings" essay and later in Souls in a revised form. The 1897 version reads:

the second decade of the American Negro's freedom was a period of conflict, of inspiration and doubt, of faith and vain questionings, of Sturm und Drang. The ideals of physical freedom, of political power, of school training, as separate all-sufficient panaceas for social ills, became in the third decade dim and overcast. They were the vain dreams of credulous race childhood; not wrong, but incomplete and over-simple. ${ }^{63}$

The version in Souls is an act of aftershadowing, as the "dark forest" Du Bois's enters on his twenty-fifth birthday metamorphoses into a "world-sea." The narrative of a male hero's calling as a father figure for his race is suddenly made unstable against the historical reality of the Middle Passage, which itself destabilized notions of gender difference. ${ }^{64}$

So dawned the time of Sturm und Drang: storm and stress to-day rocks our little boat on the mad waters of the world-sea; there is within and without the sound of conflict, the burning of body and rending of soul; inspiration strives with doubt, and faith with vain questionings. The bright ideals of the past,- physical freedom, political power, the training of brains and the training of hands, - all these in turn have waxed and waned, until even the last grows dim and overcast. Are they all wrong, - all false? No, not that, but each alone was over-simple and incomplete, - the dreams of a credulous racechildhood, or the fond imaginings of the other world which does not know and does not want to know our power.

The forest and the sea are not simply metaphors, but analytics that stress the continuity between land and water in what Kamau Brathwaite has called "tidalectics." 65 I want to sit with the notion of tides in thinking about Du Bois's pronouncement as Black Americans as "children of the moon," from a poem in Darkwater (the language of which resonates with the above passage from Souls). ${ }^{66}$ In the poem, the Earth's wings hide the "blazing Blackness" and "Almighty Wings" of the children of the moon, or the Negro people. I suspect that Du Bois here again uses the language of the "waxing and waning" (referring to the phases of the moon as illuminated from Earth) of the moon to foreground the capabilities and potential of Black Americans, in the same way that the moon's own fluctuations alter the tides on earth. More emphatically, in merging his own hero-quest (traversing a dark forest) with the collective journey of his race (across the world-sea), Du Bois is performing his own version of tidalectics. If the potential of Black Americans, that "credulous race-childhood," had been thwarted by the failures of Reconstruction and American democracy more broadly, then Du Bois's calling is to lead the struggle for a race childhood deserving of racial advancement (or progress). A radical claim made contemporaneously with Hall's childhood psychology, Du Bois's struggle is a rejection of recapitulation theory. Adolescent white males do not enact the savage impulses of their ancestors. Rather, an immature philosophy was the inevitable consequence of the era's scientific 
racism. Du Bois would lead the struggle for the full cultivation of a race (childhood), and he beckoned for others to help lead.

\section{Inverted Mirrors}

To help navigate "our little boat," Du Bois would need to situate himself in the history of Black diasporic peoples and to ask how narrating his own bildungsroman, a coming-of-age journey, would create space for narrating the bildungsroman of a people, a coming-of-age struggle where the Black child was the muse for the possibility for Black liberation after emancipation. ${ }^{67} \mathrm{Du}$ Bois absorbed the bildungsroman in Germany under the direction of Wilhelm Dilthey, who popularized the philosophy and taught Du Bois that the purpose of the human sciences was understanding (verstehen) and not explanation. ${ }^{68}$ Indeed, the bildungsroman was a spiritual guide for many New Negro artists who lent their talents to The Brownies' Book, including Jessie Fauset, Nella Larsen, and James Weldon Johnson.

With this in mind, we can reconsider the object lesson of Du Bois's youth - the memory of rejection in "Strivings" — as a coming-of-age narrative for Du Bois. It is therefore deeply selfreflexive, an "inverted mirror" on Du Bois's complicated childhood and his identity as a Black boy growing up in New England. ${ }^{69}$ For stealing fruit from a neighbor, Du Bois had nearly been sent to a reform school in the opposite corner of the state, a punishment that may have dramatically changed Du Bois's life fortunes. But aware of the young boy's talents, the local high school principal, Frank Hosmer, intervened to help spare "Willie" such castigation. Several years later, Du Bois would graduate from that high school as the only Black student in his class and as one of only several students bound for college. ${ }^{70}$ The schoolhouse memory notwithstanding - coupled with Hosmer's support-Du Bois later wrote that his childhood was largely shielded from racial animus. ${ }^{71}$

The inverted mirror also reflects how gender shaped Du Bois's experience of double consciousness. Adopting a psychoanalytic frame that reveals the currents of desire throughout Du Bois's writing, Claudia Tate asks why it is significant that Du Bois's earliest memory of racism - the moment he learned he was fated to a life behind the veil—was the result of rejection by a white girl. For Tate, this rejection is especially traumatic for Du Bois because it violated "the perfect image his mother seems to have reflected for him." denial of reciprocity by white Americans, then there is for Du Bois, as the veil descended, the layer of a gendered assault on his manhood. Du Bois would try and recuperate his manhood (in his fiction and nonfiction writing) by venerating the "mother-idea" as the pinnacle of Black womanhood, but in ways that placed limits on the political capacities of Black women.

Other psychosocial accounts have reflected on how Du Bois's absent father (Alfred Du Bois, who abandoned Du Bois and his mother, Mary Silvina, shortly after William was born) profoundly shaped Du Bois's life. Keith Byerman explains that Lacan's "law of the father," a structure of the symbolic patriarchal order, guided the master narrative of Du Bois's life: a form of ego development in which Du Bois asserted his position as a leader for his race, battling heroically against other leading men (or father figures) for the cause of the highest virtues, in Du Bois's own words, of Truth and Beauty. It is intriguing that the symbolic father figure of The Souls of Black Folk-Alexander Crummell, the influential Black minister to whom Du Bois devotes an entire chapter and whose image effectively serves as a foil to Booker T. Washington in the book - was a man who introduced himself to Du Bois as a commencement speaker at Wilberforce University, where Du Bois taught while completing his doctoral dissertation. Du Bois's relationship to Crummell is deeply ambivalent. While Crummell had followed his own 
vision splendid and was "a seer to lead" those "out of the house of bondage" (a recapitulation of "prison-house" from the "Strivings" essay), ${ }^{73}$ the minister had, in Du Bois's eyes, stumbled in not acknowledging fully how the legacy of slavery still shaped the lives and thought of Black Americans. Thus, Crummell's was "an example of alienated leadership."74 The son would learn from and then break from the father and advance a new example of leadership.

Even as the world traveler and man of letters famously projected self-confidence, Du Bois's inner life was marked by insecurity about his own family and as a child of his descendants. While his forebears had been property owners, Du Bois and his mother were on precarious financial footing and experienced downward mobility. ${ }^{75}$ Du Bois took great care in his autobiographies and for his own records to chronicle his paternal and maternal genealogies, but this process, too, was marked by incompleteness and aftershadowing. Nahum Chandler has scrutinized what this process meant for Du Bois's own racial identity/identification, and I want to emphasize a few points here. In Souls, Du Bois identifies most with his maternal (Burghardt) line, but decades later Du Bois turns his attention to his paternal (Du Bois) line. In Dusk of Dawn, he describes at length the influence of his great-grandfather, Dr. James Du Bois, a white slaveowner from the Bahamas who may have descended from nobility. James Du Bois had a slave as a common-law wife and together they had two sons, including Alexander, W. E. B.'s grandfather. The sons "were white enough in appearance to give no inkling of their African descent."76 In a typed chart from around 1932 tracing his paternal and maternal lines, Du Bois makes clear how his family genealogy was marked by, in his words, the "fascinating" reality of "intermixture"77 (see Figure 1). The identity of his great-grandmother is unknown. She is listed as "mulatto." Du Bois's maternal line begins with "Slave of Dutch."

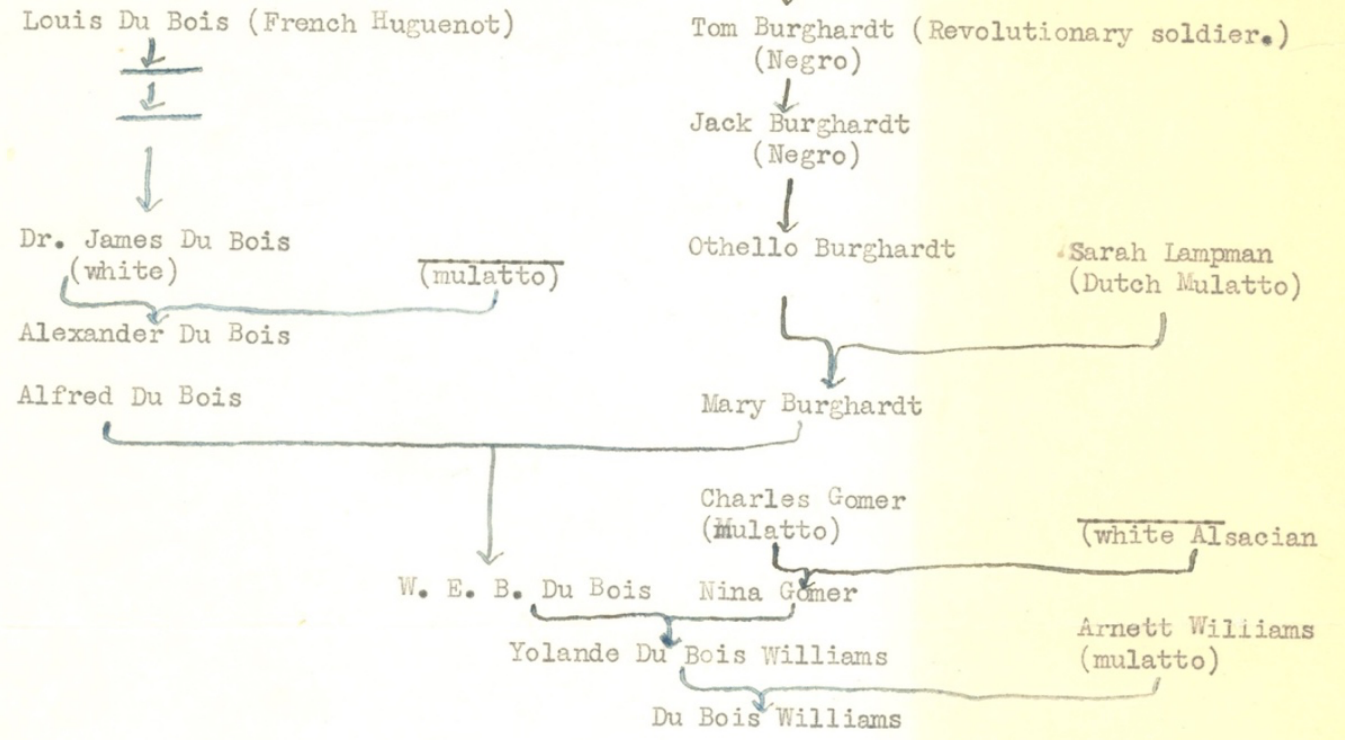

Figure 1. W. E. B. Du Bois Family Tree, ca. 1932, Department of Special Collections and University Archives, W. E. B. Du Bois Library, University of Massachusetts, Amherst. 
In 1953, eleven years before his death, Du Bois and his second wife, Shirley Graham Du Bois, traveled to the Bahamas in search of more information on W. E. B.'s great-grandfather and grandfather. The visit is chronicled in Graham Du Bois's memoir of her husband. ${ }^{78}$ The visit yielded as many questions as answers. The residents of Long Cay greeted its "most illustrious son" warmly. Du Bois was compulsive about protecting and preserving his own personal archive, so he was disappointed to learn that the island was not in possession of any official records of the Du Bois family. Instead, what he learned from the island's elders - who gave the "Du Bois" name the French pronunciation that Du Bois himself had rejected ${ }^{79}$ —was that the Du Bois men had had many children and mistresses. Knowledge of official marriages was limited. The name of his grandfather's mother - the slave mother - remained unknown. An old woman who surmises she is a distant relative of Du Bois tells W. E. B. and Shirley that "these islands were full of Duboises - in all colors and shapes"; the three of them then "laughed over their varicolored and virile family."

Du Bois's genealogical investigations destabilized notions of hereditary purity and the distinct boundedness of race (too easily assumed, ironically, in Du Bois's own famous notion of a "color-line"). Du Bois reckons with the historical reality and pervasiveness of "intermixture" in the US South and the Caribbean - a consequence of chattel slavery and violent colonizationdespite how "scientific study in this direction might lead to conclusions with which we were loath to agree." 80 This "desedimentation" (in the words of Naham Chandler) of his family genealogies motivated $\mathrm{Du}$ Bois to strive to find his place in the world. While $\mathrm{Du}$ Bois was resolute in his conviction in a gospel of collective uplift, he would ponder for his entire life how his own family history shaped his coming-of-age (heading into the dark forest and taking up the mantle of racial struggle) and, by extension, the coming-of-age of a people. The collective memory of the islands was a memory of intermixture. There was clarity regarding the islands' colonial past, but there would remain a "penumbra of vagueness" regarding Du Bois's own ancestry. But the residents of Long Cay were living with dignity and joy. To borrow from a reflection by Caribbean artist Kamau Brathwaite, when these residents walked on sand (the land), they also walked on water. They were also on a journey, in transition, between past and future, as their movement kept "the ebb and flow of the tides touching the shores of the continent of Africa and the coasts of the Caribbean." 81

\section{An Ocean Lay Between}

During his visit to Long Cay, Du Bois, then eighty-five years old, was reflecting on his ancestral history at a moment when he was also looking ahead, to consider how history would look back and remember him. The visit came at an especially challenging period in Du Bois's life. Given his political agenda of decolonization and global revolution, he was branded a "suspect citizen"- a racialized classification for those whose loyalty to America and its causes is perpetually in doubt ${ }^{82}$ — and was the subject of FBI surveillance during the early Cold War era. In 1951, he was indicted and forced to stand trial for being a foreign agent. "I bowed before the storm," Du Bois wrote in his autobiography. "But I did not break." 83 While he was acquitted, he had been spurned by the civil rights establishment. Colleges no longer invited him to be their commencement speaker. In some cases, the NAACP, the organization he had helped found, blocked his campus visits. Du Bois was to be kept away from young people. "The colored children ceased to hear my name," Du Bois wrote.

Yet just as many children came to learn of Du Bois's name when they flipped through The Brownies' Book one hundred years ago — as well as the names of many other Black writers 
and artists who helped create the magic of that publication-Du Bois's life and teachings have lived on in many publications for young adults. ${ }^{84}$ Indeed, one of the best introductions to $\mathrm{Du}$ Bois remains Virginia Hamilton's 1972 biography. The book ends at the August 28, 1963, March on Washington, where it was announced that Du Bois had died the day before in Ghana. Using language that drew a spiritual connection between Du Bois and Martin Luther King Jr., Hamilton writes: "An ocean lay between the Doctor's death and our lives, but that didn't matter. He was our great man, our keeper, and we were his dream. The distance between us was never far." 85 The tides united them, as younger generations had joined the cause of racial struggle, drew inspiration from Du Bois's words, and followed their own freedom dreams. They were "looking forward into the past," 86 like a boomerang in flight tracing the enduring promise of race childhood.

\section{Notes}

1. W. E. B. Du Bois, "Strivings of the Negro People," The Atlantic, https://www.theatlantic.com/magazine/archive/1897/08/strivings-of-the-negro-people/305446/. 2. Crystal Lynn Webster, "“Transfiguring the Soul of Childhood': Du Bois's Private Vision and Public Activism for Black Children," Journal of the History of Childhood and Youth 14, no. 3 (2021): 347-66. For a reflection on how Burghardt's death shaped Du Bois's experience of and thinking on trauma, see Freeden Blume Oeur, "Fever Dreams: W. E. B. Du Bois and the Racial Trauma of COVID-19 and Lynching," Ethnic and Racial Studies 44, no. 5 (2021): 735-45. 3. Keith Byerman, Seizing the Word: History, Art, and Self in the Work of W. E. B. Du Bois (Athens: University of Georgia Press, 2010), 8.

4. Claudia Tate, Psychoanalysis and Black Novels: Desire and the Protocols of Race (New York: Oxford University Press, 1998), 10; R. A. Judy, Sentient Flesh: Thinking as Disorder, Poiesis in Black (Durham: Duke University Press, 2020), 401.

5. Paul Taylor, "What's the Use of Calling Du Bois a Pragmatist?" Metaphilosophy 35, no. 1/2 (2004): 99-114.

6. W. E. B. Du Bois, The Souls of Black Folk: Essays and Sketches (Amherst: University of Massachusetts Press, [1903] 2018), 10.

7. G. Stanley Hall, 1844-1924. Letter from G. Stanley Hall to W. E. B. Du Bois, December 9, 1904, W. E. B. Du Bois Papers (MS 312), Special Collections and University Archives, University of Massachusetts Amherst Libraries, https://credo.library.umass.edu/view/full/mums312-b002-i327. Hall refers to Du Bois's writings on the Negro church as "very valuable publications." See also G. Stanley Hall, 1844-1924. Letter from G. Stanley Hall to W. E. B. Du Bois, December 15, 1905, W. E. B. Du Bois Papers (MS 312), Special Collections and University Archives, University of Massachusetts, Amherst Libraries, https://credo.library.umass.edu/view/full/mums312-b002-i328.

8. Tate, Psychoanalysis and Black Novels, 10.

9. Du Bois, The Souls of Black Folk, 1.

10. Nahum Dimitri Chandler, X: The Problem of the Negro as a Problem for Thought (New York: Fordham University Press, 2014), 7. 11. Jean-Christophe Cloutier, Shadow Archives: The Lifecycles of African American Literature (New York: Columbia University Press, 2019).

12. Nahum Dimitri Chandler, Toward an African Future - of the Limit of World (London: Living Commons Collective, 2013), 99. For Chandler, these afterthoughts are those which stand 
"beyond the close of the concluding chapter"; therefore, an idea can be both an epigraph and an afterthought. My own thinking about ends-as-beginning stresses the way that ideas travel helically as well as how Du Bois's predilection for foreshadowing and aftershadowing is not a matter of bracketing (or foreclosing) ideas, but how ideas are perpetually open-ended for Du Bois, remaining in dynamic tension with one another.

13. Kwame Appiah, Lines of Descent: W. E. B. Du Bois and the Emergence of Identity (Cambridge: Harvard University Press, 2014), 61.

14. Katherine McKittrick, Dear Science: And Other Stories (Durham: Duke University Press, 2021), 45-6. Citing Édouard Glissant, Poetics of Relation, trans. Betsy Wing (Ann Arbor: University of Michigan Press, 1997), 9.

15. Brent Hayes Edwards, The Practice of Diaspora: Literature, Translation, and the Rise of Black Internationalism (Cambridge: Harvard University Press, 2009).

16. W. E. B. Du Bois, The Autobiography of W. E. B. Du Bois: A Soliloquy on Viewing My Life from the Last Decade of Its First Century (New York: Oxford University Press, [1968] 2007). 17. W. E. B. Du Bois, Dusk of Dawn: An Essay Toward an Autobiography of a Race Concept (New York: Oxford University Press, [1940] 2007).

18. David Farrell Krell, "The Bodies of Black Folk: From Kant and Hegel to Du Bois and Baldwin," boundary 2 27, no. 3 (2000): 103-34, 113.

19. Tiffany Lethabo King, The Black Shoals: Offshore Formations of Black and Native Studies (Durham: Duke University Press, 2019).

20. W. E. B. Du Bois, Darkwater: Voices from Within the Veil (Mineola: Dover, [1920] 1999), ix.

21. Chandler's paleonymic method of analysis borrows from Derrida; see $X$.

22. Du Bois will use this phrase in a 1904 self-review of The Souls of Black Folk. See Herbert Aptheker, ed., Book Reviews by W. E. B. Du Bois (Millwood: KTO Press), 9.

23. Katharine Capshaw, "Come On In!': Play as Community and Liberation in The Brownies' Book," Journal of the History of Childhood and Youth 14, no. 3 (2021): 367-92.

24. Sarah Anne Carter, Object Lessons: How Nineteenth-Century Americans Learned to Make Sense of the Material World (New York: Oxford University Press, 2018).

25. Keeanga-Yamahtta Taylor, “The Black Plague,” New Yorker, April 16, 2020, https://www.newyorker.com/news/our-columnists/the-black-plague.

26. Du Bois, The Souls of Black Folk.

27. Du Bois, Dusk of Dawn, 6-7.

28. David Levering Lewis, W. E. B. Du Bois: Biography of a Race, 1868-1919 (New York: Henry Holt and Co., 1993).

29. Valerie L. Williams-Sanchez, "Celebrating the Anniversary of THE BROWNIES' BOOK by W. E. B. Du Bois,” We Need Diverse Books, April 27, 2020, https://diversebooks.org/celebrating-the-anniversary-of-the-brownies-book-by-w-e-b-dubois/. 30. The perceived sexual advances of Black men towards white women were used, for example, to justify the lynching of Black men, which Du Bois wrote about himself at length. As Lewis observes in W. E. B. Du Bois, this "newcomer" was likely a girl by the name of Agnes O'Neill, whom Du Bois refers to years later in his autobiography. Du Bois may have harbored some resentment even after all those years, as he described her as "negligible." See Du Bois, The Autobiography of W. E. B. Du Bois, 54.

31. Carter, Object Lessons, 94. The institution also enrolled Native American students.

32. See "History," Hampton University, https://www.hamptonu.edu/about/history.cfm. 
33. Cited in Carter, Object Lessons, 110.

34. For more on how Washington himself frequently deployed the idea of object lessons, see Carter, Object Lessons. To be sure, the idea that Washington and Du Bois were ideologically opposed to one another is too tidy a narrative, and scholars like Robert J. Norrell have challenged the perception that Washington was an "obedient accommodationist." There is something to Norrell's related claim that Washington (like Du Bois) has become an "elastic emblem" in thinking about African American intellectual history and politics, given his outsized influence in tradition. As Norrell writes, Washington "clearly recognized his symbolic role . . but often he failed to persuade his audience of the object lessons he meant to teach." See "Booker T.

Washington: Understanding the Wizard of Tuskegee," Journal of Blacks in Higher Education, 42 (2003-04): 96-109, 96.

35. W. E. B. Du Bois, "The Hampton Idea (1906)," in The Education of Black People: Ten Critiques, 1906-1960, ed. Herbert Aptheker (New York: Monthly Review Press), 21-32, 21. 36. Du Bois, "The Hampton Idea," 30-1.

37. Progressive educators have turned to Wordsworth's poem to help develop a critical consciousness in young people. See Jeffrey C. Robinson, Radical Literacy Education: A Classroom Experiment with Wordsworth's 'Ode' (Madison: University of Wisconsin Press, 1987).

38. W. E. B. Du Bois, "Careers Open to College-Bred Negroes," in W. E. B. Du Bois Speaks: Speeches and Addresses, 1890-1919, ed. Philip S. Foner (New York: Pathfinder Press, 1980), 86-101, 87.

39. Du Bois, "Careers Open to College-Bred Negroes," 87.

40. Robert Gooding-Williams, In the Shadow of Du Bois: Afro-Modern Political Thought in America (Cambridge: Harvard University Press, 2009).

41. Du Bois, The Souls of Black Folk, 257. Emphasis in the original.

42. Mickenzie Fasteland, "Reading the Antimodern Way: G. Stanley Hall's Adolescence and Imperialist Reading for White American Boys," Journal of the History of Childhood and Youth 12, no. 1 (2019): 7-25.

43. These psychologists included James Mark Baldwin and M. J. Mayo. See Caroline F.

Levander, Cradle of Liberty: Race, The Child, and National Belonging from Thomas Jefferson to W. E. B. Du Bois (Durham: Duke University Press, 2006).

44. G. Stanley Hall, Adolescence: Its Psychology and its Relations to Physiology, Anthropology, Sociology, Sex, Crime, Religion, and Education, Vol. 1 (New York: D. Appleton and Co., 1904), xiii.

45. Hall, Adolescence, Vol. 1.

46. Hall, Adolescence, Vol. 1, 543.

47. G. Stanley Hall, Adolescence: Its Psychology and its Relations to Physiology, Anthropology, Sociology, Sex, Crime, Religion, and Education, Vol. 2 (New York: D. Appleton and Co., 1904), 677.

48. Booker T. Washington, "The Negro and the Labor Problem of the South," in The Booker T. Washington Papers, Vol. 8: 1904-6, eds. Louis R. Harlan and Raymond W. Smock (Urbana: University of Illinois Press, 1979), 139-45, 144-5.

49. Fasteland, "Reading the Antimodern Way," 19.

50. G. Stanley Hall, "The Negro in America and Africa," The Pedagogical Seminary 12, no. 3 (1905): 350-68, 366. And later: "I doubt if any educational institution in the world's history ever 
showed, in those who attend from year to year, greater progress along so many lines,- - dress, manners, intelligence, morals, health, - than is seen in the pupils of Tuskegee," 367.

51. José Itzigsohn and Karida L. Brown, The Sociology of W. E. B. Du Bois: Racialized Modernity and the Global Color Line (New York: NYU Press, 2020).

52. Hall, Adolescence, Vol. 1, 533-4.

53. Simply put, for Hall, Goethe was an object lesson for the greatness of human potential. As Dorothy Ross has written, "Evolutionary biology provided Hall with the vision of one's psyche as a microcosm of the entire living world, as a composite inheritance of the past, as an "echochamber" reverberating with the whispers of ancestors." G. Stanley Hall: The Psychologist as Prophet (Chicago: University of Chicago Press, 1972), 256.

54. Goethe was Du Bois's "favorite." See Christa Buschendorf and Cornel West, "A Figure of Our Times': An Interview with Cornel West on W. E. B. Du Bois," Du Bois Review 10, no. 1 (2013): 261-78.

55. Jennifer A. Herdt, Forming Humanity: Redeeming the German Bildung Tradition (Chicago: University of Chicago Press, 2019), 82. While in Germany, Du Bois wrote a letter to the Fisk student paper praising Goethe's insights for the study of racial progress; see Eugene Victor Wolfenstein, A Gift of the Spirit: Reading The Souls of Black Folk (Ithaca: Cornell University Press, 2007).

56. Du Bois, The Autobiography of W. E. B. Du Bois, 107.

57. Lewis, W. E. B. Du Bois.

58. W. E. B. Du Bois, "Celebrating His Twenty-fifth Birthday (1893)," in Against Racism: Unpublished Essays, Papers, and Addresses, 1887-1961, ed. Herbert Aptheker (Amherst: University of Massachusetts Press), 26-29, 28. The Divine Comedy begins with Dante the Pilgrim lost and alone: "Midway along the journey of our life, I woke to find myself lost in a dark wood." See Dante, The Divine Comedy, Volume 1: The Inferno, translated by Mark Musa (New York: Penguin Classics, 2002). Other contemporary translations substitute "forest" for "wood." The Divine Comedy has been a major source of inspiration for Black artists; see Dennis Looney, Freedom Readers: The African American Reception of Dante Alighieri and the Divine Comedy (Notre Dame: Notre Dame University Press, 2011). While Looney suggests the influence of Dante on Du Bois, the author never specifies exactly how Du Bois likely interpellated the figure of the pilgrim for Du Bois's own quest through hellfire.

59. W. E. B. Du Bois, 1868-1963. Program for the Celebration of My Twenty-fifth Birthday, ca. February 24, 1893, W. E. B. Du Bois Papers (MS 312), Special Collections and University Archives, University of Massachusetts, Amherst Libraries.

60. In the tragedy, Faust famously revises/translates "In the beginning was the word" from the Bible as "In the beginning was the deed." This encapsulates the essence of striving. 61. My analysis therefore hews closely to that of Appiah, Lines of Descent. While Du Bois's own language evokes Faust, Goethe's various novels on the journeys and apprenticeship of "Wilhelm Meister" also provided a template for striving and resonated with Du Bois's language in his twenty-fifth birthday program.

62. Roy Pascal, “The 'Sturm und Drang' Movement," Modern Language Review 47, no. 2 (1952): 129-51, 150.

63. W. E. B. Du Bois, "Strivings of the Negro People."

64. Hortense Spillers writes: "Those African persons in 'Middle Passage' were literally suspended in the 'oceanic,' if we think of the latter in its Freudian orientation as an analogy for undifferentiated identity: removed from the indigenous land and culture, and not-yet 'American' 
either, these captive persons, without names that their captors would recognize, were in movement across the Atlantic, but they were also nowhere at all. Inasmuch as, on any given day, we might imagine, the captive personality did not know where s/he was, we could say that they were the culturally 'unmade,' thrown in the midst of a figurative darkness that 'exposed' their destinies to an unknown course. .. . Under these conditions, one is neither female, nor male, as both subjects are taken into 'account' as quantities." See "Mama's Baby, Papa's Maybe: An American Grammar Book," Diacritics 17, no. 2 (1987): 64-81, 72.

65. Kamau Brathwaite, ConVERSations with Nathaniel McKay (Rhinebeck: We, 1999). 66. W. E. B. Du Bois, "Children of the Moon," in Darkwater: Voices from Within the Veil (Mineola: Dover, [1920] 1999), 109-13, 110.

67. Mary Niall Mitchell, Raising Freedom's Child: Black Children and Visions of the Future after Slavery (New York: NYU Press, 2008).

68. Mark Whalen, "The Bildungsroman in the Harlem Renaissance," in A History of the Harlem Renaissance, eds. Rachel Fairbrother and Miriam Thaggert (London: Cambridge University Press, 2021), 72-88. Appiah, Lines of Descent.

69. "Inverted mirror" is from Shawn Michelle Smith, Photography on the Color Line: W. E. B. Du Bois, Race, and Visual Culture (Durham: Duke University Press, 2004).

70. Lewis, W. E. B. Du Bois.

71. As Du Bois wrote in Dusk of Dawn (in a chapter on his upbringing that he would reiterate in his final autobiography), "I presume I was saved evidences of a good deal of actual discrimination by my own keen sensitiveness ... in the ordinary social affairs of the village ... in all these I took part with no thought of discrimination on the part of my fellows, for that I would have been the first to notice," 7.

72. Tate, Psychoanalysis and Black Novels.

73. Du Bois, The Souls of Black Folk, 209.

74. Robert Gooding-Williams, “Du Bois's Counter-Sublime," Massachusetts Review 35, no. 2 (1994): 202-24, 203.

75. Allison Davis, Leadership, Love \& Aggression: As the Twig is Bent, the Psychological Factors in the Making of Four Black Leaders (New York: Harcourt Brace, 1983). Davis suggests that because his own mother had an illegitimate son, Du Bois himself worried that he was illegitimate.

76. Du Bois, Dusk of Dawn, 53.

77. Du Bois, Dusk of Dawn, 52.

78. Shirley Graham Du Bois, His Day is Marching On: A Memoir of W. E. B. Du Bois

(Philadelphia: J. B. Lippincott \& Co., 1971).

79. Du Bois insisted that his surname be pronounced "Dew-boys" with the stress on the second syllable, unlike the expected Gallic pronunciation "Dew-bwah." See Lewis, W. E. B. Du Bois.

80. Du Bois, Dusk of Dawn, 52.

81. I am inspired here by Tiffany Lethabo King's reading of Braithwaite's tidalectics, grounded in a memory Brathwaite has of watching a Jamaican woman sweep the sand off her yard. See The Black Shoals.

82. Eric Porter, The Problem of the Future World: W. E. B. Du Bois and the Race Concept at Midcentury (Durham: Duke University Press, 2010). For more on Du Bois's revolutionary latecareer politics, see Phillip Luke Sinitiere, ed., Citizen of the World: The Late Career and Legacy of W. E. B. Du Bois (Evanston: Northwestern University Press, 2019).

83. Du Bois, Dusk of Dawn, 255. 
84. For a bibliography of young adult literature on Du Bois, see Phillip Luke Sinitiere, “A Legacy of Scholarship and Struggle': W. E. B. Du Bois's Life after Death," in Citizen of the World: The Late Career and Legacy of W. E. B. Du Bois, ed. Phillip Luke Sinitiere (Evanston: Northwestern University Press, 2019), 227-66.

85. Virginia Hamilton, W. E. B. Du Bois: A Biography (New York: HarperCollins, 1972), 197. 86. For a recent exposition of how Du Bois's notion of "looking forward into the past" (from a 1946 Chicago Defender column) could be "an admonition and a methodology," see Phillip Luke Sinitiere, "The Black Futures of W. E. B. Du Bois," in Critical Black Futures: Speculative Theories and Explorations, ed. Philip Butler (Singapore: Palgrave MacMillan, 2021), 19-36, 20. 